\title{
ACOUSTIC EMISSION IN SNOW AT GONSTANT RATES OF DEFORMATION
}

\author{
By W. F. St. LaWrence, \\ (Department of Earth Sciences, Montana State University, Bozeman, Montana 59715, U.S.A.) \\ T. E. LANG, R. L. BRown \\ (Department of Civil Engineering and Engineering Mechanics, Montana State University, Bozeman, \\ Montana 597 I5 , U.S.A.) \\ and C. C. BRAdley \\ (Department of Earth Sciences, Montana State University, Bozeman, Montana 59715, U.S.A.)
}

\begin{abstract}
ABSTRACr. Acoustic emissions in the audio spectrum are reported from observations of laboratory experiments conducted on snow samples in uniaxial compression. A number of tests show the pattern of acoustic emissions to be a function of the rate of deformation. Over the frequency range 20 to $7 \mathrm{ooo} \mathrm{Hz}$ acoustic emissions are associated with rates of deformation corresponding to brittle fracture of the snow sample. Though probably present, no acoustic emissions were detected from samples deforming plastically.

RÉsumÉ. Émission acoustique dans la neige à vitesse constante de déformation. On rend compte d'émissions acoustiques dans le spectre audible, à partir d'expériences de laboratoire conduites sur des échantillons de neige en compression semi-axiale. De nombreux essais montrent que le comportement des émissions acoustiques est une fonction du taux de déformation. Dans la gamme des fréquences de 20 à $7000 \mathrm{~Hz}$, les émissions acoustiques sont associées à des taux de contrainte correspondant à la rupture de l'échantillon de neige. Bien qu'il y en ait probablement, aucune émission acoustique n'a été détectée à partir d'échantillons soumis à une déformation plastique.
\end{abstract}

Zusammenfassung. Akustische Emissionen in Schnee bei konstanter Deformationsgeschwindigkeit. Über akustische Emissionen im hörbaren Bereich wird auf Grund von Beobachtungen bei Laborversuchen an Schneeproben unter einachsiger Kompression berichtet. Die Art des akustischen Emissionen ergibt sich aus einer Anzahl von Versuchen als eine Funktion der Deformationsgeschwindigkeit. Über den Frequenzbereich von 20 bis $7000 \mathrm{~Hz}$ sind akustische Emissionen mit Spannungsraten verbunden, die der Festigkeit der Schneeproben gegen spröde Brüche entsprechen. Obgleich wahrscheinlich vorhanden, wurden keine akustischen Emissionen bei plastischer Verformung der Proben festgestellt.

Acoustic emission is defined as low-level sound or pressure waves in materials (Liptai and others, 1972). Included are infrasonic, sonic and ultrasonic disturbances, all transient in nature. The source of these emissions is the release of internal energy from crystal dislocations and intercrystal fracturing. In current acoustic emission applications the disturbances are triggered by load or temperature inputs. Different materials exhibit different emission spectra with load.

It has been observed that snow samples subjected to various rates of deformation in uniaxial compression exhibit three types of behavior up to failure (Kinosita, 1967). At slow rates non-linear inelastic deformation follows low-stress linear visco-elastic response. At intermediate rates, approximately linear-appearing stress response is terminated by brittle fracture, followed by material rebonding and repeated stress build-up at the same linear rate, this cycle repeating with continued deformation. This mechanism may be considered brittle failure of the first type. At relatively high deformation rates failure occurs by continuous end spalding at constant load, suggestive of strong end constraint effects. This may be termed brittle failure of the second type.

The results reported by Kinosita (1967) were verified in the course of our acoustic emission tests. For $0.3 \mathrm{Mg} \mathrm{m}^{-3}$ snow tested at temperatures between $\mathrm{o}^{\circ}$ and $-10^{\circ} \mathrm{C}$ the following critical velocities were observed by the authors. For rates of deformation less than $0.05 \mathrm{~mm} \mathrm{~s}^{-1}$ the snow responded with continuous inelastic deformation. For deformation rates greater than $0.05 \mathrm{~mm} \mathrm{~s}^{-1}$ but less than I. $15 \mathrm{~mm} \mathrm{~s}^{-1}$ brittle failure of the first type was observed. For deformation rates in excess of $1.15 \mathrm{~mm} \mathrm{~s}^{-1}$ brittle failure of the second type was encountered. In these tests right circular cylinders $\mathrm{I} 4 \mathrm{O} \mathrm{mm}$ long and $100 \mathrm{~mm}$ in diameter were obtained by coring early-season alpine snowpack. The specimens were stored at $-30^{\circ} \mathrm{C}$ prior to testing and brought to $-2^{\circ} \mathrm{C} \pm 2^{\circ}$ for testing. Densities varied between 0.29 and $0.3 \mathrm{I} \mathrm{Mg} \mathrm{m}^{-3}$. 
The emissions were monitored by a geophone mounted to a base plate upon which the specimen rested on an Instron testing machine. The geophone was modified for flat low-frequency response, and had adequate sensitivity over a frequency range 20 to $8000 \mathrm{~Hz}$. The broad-band signal from the geophone was amplified $(\times 300)$, band-pass filtered (between 15 and $20000 \mathrm{~Hz}$ ), recorded on magnetic tape and monitored on an oscilloscope during the test. Data analysis involved recording the acoustic signal on a light-writing oscillograph after processing it through a full-wave rectifier.

Experimental results obtained are consistent and typical of the acoustic emission characteristic of other materials (Goodman, I963). Figure $\mathrm{I}$ illustrates spectra of emissions obtained at a deformation rate of $0.13 \mathrm{~mm} \mathrm{~s}^{-1}$. At this rate the snow sample exhibited brittle failure of the first type with successive failures occurring with a period of $15 \mathrm{~s}$. In this figure each emission that was recorded is represented as a vertical line. Figure $\mathrm{ra}, \mathrm{b}$ and $\mathrm{c}$ each indicate the emission sequence between successive collapses.

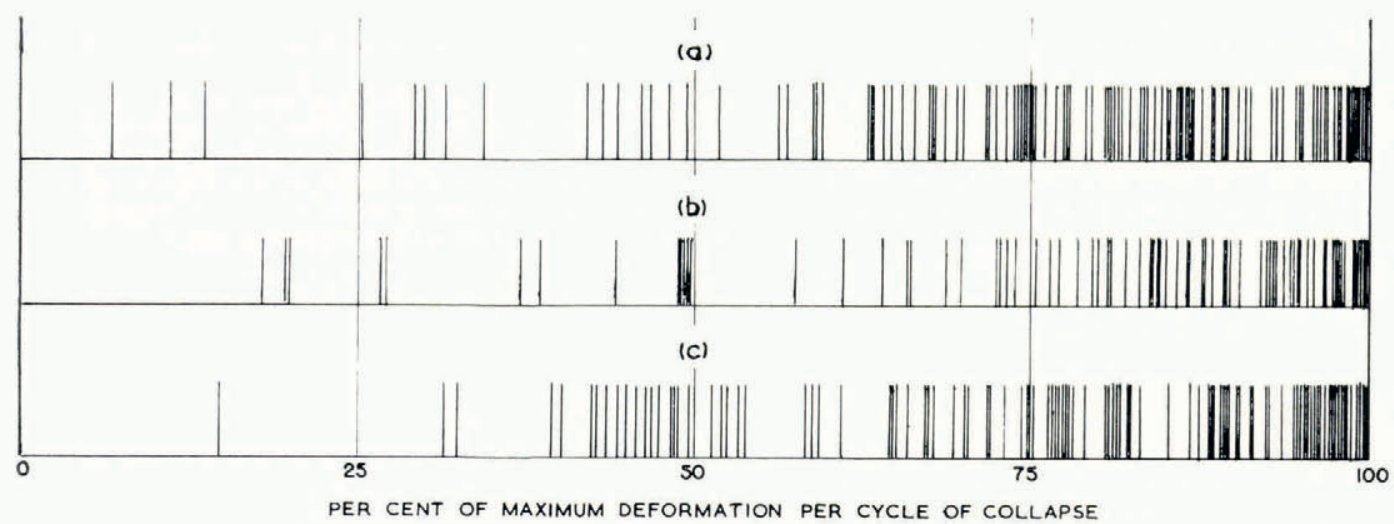

Fig. I. Occurrence of acoustic emissions as a percentage of maximum deformation for each cycle of collapse at a deformation rate of $0.13 \mathrm{~mm} \mathrm{~s}^{-1}(a)$ between zero and first collapse, $(b)$ between first and second collapse, $(c)$ between second and third collapse.

In the range of brittle failure of the first type, at rates below $0.5 \mathrm{~mm} \mathrm{~s}^{-1}$ a failure plane develops within the specimen terminating the gradual intensification of acoustic bursts (Fig. 1a). Each burst represents frequency content from $\mathrm{i} 5$ to $5000 \mathrm{~Hz}$, with predominant frequencies below $2 \mathrm{ooo} \mathrm{Hz}$. Single bursts are sub-audible, the phenomena becoming audible with burst densification near collapse. Following initial collapse, two cycles of reloading at the same deformation rate produce the burst spectra depicted in Figure $\mathrm{Ib}$ and $\mathrm{c}$. At each subsequent brittle failure the specimen deflects at the same failure plane as in the initial collapse. Over the entire brittle-failure deformation-rate range $\left(0.05^{-0.5}\right.$ $\mathrm{mm} \mathrm{s}^{-1}$ ) distinct and patterned emission spectra are observed. Although brittle failure of type one occurred at rates greater than $0.5 \mathrm{~mm} \mathrm{~s}^{-1}$, the failure observed took place at the ends of the specimens.

At low deformation rates corresponding to inelastic deformation, no detectable acoustic emissions were observed, in contrast to readily detected emissions in the brittle-failure range. For deformation rates at which failure occurred at the ends of the specimen no pattern of emissions was established. For rates that produced constant failure continuous audible noise was detected.

Kinosita (1967) reported that the distinction between inelastic response and brittle-failure response corresponds respectively to intracrystalline slip versus intercrystalline fracture. Thus acoustic emissions probably occur during material flow as dislocations align in single crystals. However, either these dislocations occur at intensities and non-reinforcing rates that preclude detection, or they emit at higher frequencies than those detectable by the monitoring system used. In the case of intercrystal fracture, the fracture either spans several crystal boundaries or a cascade of fractures reinforces to produce a signal of detectable intensity.

Laboratory and field experiments are now in progress to attempt to answer numerous questions that remain concerning acoustic emissions from snow. These preliminary results indicate that acoustic emission techniques in laboratory and field applications may be a new and productive tool in snow mechanics. 


\section{AcKNOWLEDGEMENTS}

The authors wish to thank Dr Glen L. Martin, Head of the Department of Civil Engineering and Engineering Mechanics, and Dr James L. Knox, Professor of Electrical Engineering and staff member of the Electronics Research Laboratory of Montana State University, for their support and interest in this work. The research is supported in part by grant No. DA-ARO-D-31-124-7 I-G59 from the Army Research Office, Durham, North Carolina.

MS. received 3 Fanuary 1972 and in revised form ${ }_{14}$ March 1972

\section{REFERENGES}

Goodman, R. E. 1963. Subaudible noise during compression of rocks. Geological Society of America. Bulletin, Vol. 74 , No. 4, p. 487-9o.

Kinosita, S. 1967. Compression of snow at constant speed. (In Oura, H., ed. Physics of snow and ice: international conference on low temperature science.... $1966 \ldots$ Proceedings, Vol. I, Pt. 2. [Sapporo], Institute of Low Temperature Science, Hokkaido University, p. 911 - -27.$)$

Liptai, R. G., and others. 1972. An introduction to acoustic emission, by R. G. Liptai, D. O. Harris and C. A. Tatro. (In Proceedings of the Symposium on acoustic emission, Bal Harbor, Florida, December 7-8, 197I. Philadelphia, Pa., American Society of Testing and Materials, p. 3-10. (Special Technical Publication 505.)) 